\title{
Cooperative Learning Model with Jigsaw Type Improves Students" Sciences Process Skills and Learning Outcomes
}

\section{Fransiska Purwantini Soedimardjono ${ }^{1 *}$, Pratiwi P2}

${ }^{12}$ Basic Education, Postgraduate Program, State University of Yogyakarta, Indonesia e-mail: fransiskapurwantini@gmail.com ${ }^{1}$, pratiwi@uny.ac.id ${ }^{2}$

\begin{abstract}
This study aims to improve science process skills and learning outcomes with Classroom Action Research using a jigsaw-type cooperative learning model. This research is a classroom action research conducted in two cycles. Learning outcomes before the results of the study using a jigsaw cooperative model is 33\%. The results showed that an increase in student learning outcomes in the initial research, cycle I, and cycle II. The average value, in the initial study the average value of the class test was 57.33 in the first cycle, the average grade was 82.66, and in the second cycle, the average grade was 86.66. In addition, the number of students who graduated also increased, in the initial study the number of students who graduated was only 10 people (33\%), and 20 other people $(67 \%)$ did not graduate. In the first cycle the number of students who graduated increased to 26 people (87\%) students who did not pass 4 people (13\%). An increase in the number of students who graduated was also seen in cycle II the number of students who passed 30 people (100\%) or thus learning with the Jigsaw Cooperative model was more appropriate to be carried out so that all students graduated.
\end{abstract}

Keywords: Process skills, Learning outcomes, Jigsaw.

\section{Introduction}

Natural science education (IPA) is an effort or process to teach students to understand the nature of science which includes: products, processes, and developing scientific attitudes and being aware of the values that exist in society for the development of attitudes and actions in the form of positive science applications. The objectives of science education include: Knowledge and understanding, exploration and discovery, imagination and creativity, attitude and science, and application (Cahyani, Ardana, Ganing, 2016; Lai \& Wu, 2006). Natural Science (IPA) is essentially a collection of knowledge obtained through a scientific process by way of thinking and investigation that shapes scientific attitudes, and interacts with technology so that it can be applied in everyday life, both at school and in society (Cahyani et al., 2016). The teacher's task in the learning process is to plan learning, carry out learning, and carry out assessment of learning outcomes. the implementation of the learning process has been arranged in a process standard.

The education component that really determines the implementation of the education process properly is the teacher. In all education systems, teacher performance is one of the main factors determining school effectiveness and learning outcomes (Harden, 2002; Hussey \& Smith, 2008). Not many teachers are able to carry out their roles and functions adequately. The problems faced come from the facilities, the local school social culture, or the education system. Teachers are required to be able to manage teaching, namely in determining strategies and planning and ending with an assessment. Teachers are people who have the ability to design learning programs and are able to organize and manage classes so that students can learn (Krisno, 2016). Teachers can be defined as people whose duties are related to efforts to educate the nation's life in all its aspects, both spiritual and emotional, intellectual, physical, and other aspects (Arikunto, 2010; Tsay \& Brady, 2010). From the above understanding it can be concluded that the teacher is a profession that is legally formal and informal that is tasked with educating the life of the nation with the ability to

\footnotetext{
${ }^{*}$ Corresponding author.

Received 04 June 2020; Accepted 16 December 2020; Available online 01 March 2021 (c) 2020 JPI. All Rights Reserved
} 
design learning programs used to carry out their main duties in educating, teaching, guiding and evaluating students both in class and outside the classroom.

The learning process in the classroom is a black box which should get more serious attention from the teacher, without having to ignore the instrumental input (Arends, 1997; Ongowo \& Indoshi, 2013). From the observations of science learning found in the field, the teacher still uses the lecture method. Most of the science lessons at SD Tunjungsari 2 are still carried out conventionally. This can be seen from the inability of students to solve real problems faced in their lives (Cooper, 1990). This conventional learning provides more theories that are not rooted in the real world of students. The learning only pours as much knowledge into the heads of students (Gürses, Çetinkaya, Doğar, Şahin, 2015). Meanwhile, students attend class generally not with a blank head, but they have brought a number of experiences or ideas that were formed previously when they interacted with their environment (Novianto \& Mustadi, 2015). This means that before learning takes place students actually have brought a number of ideas or ideas that have been obtained previously.

Science learning is less attractive in the eyes of students, this predicate will continue to stick, where when the teachers carry out learning only mediocrely without any effort to innovate (Brotherton \& Preece, 1995). The reality in the field speaks differently, learning especially science learning is still dominated by conventional learning with its characteristic that is teacher-centered learning. As a result, the teacher is the only source of knowledge. Teachers always use the easiest method, the lecture method (Novianto \& Mustadi, 2015). The distinctive feature of this method is that students listen, then record what the teacher said, and then finally memorize the material. In science learning, the teacher uses the lecture method, students only listen to the teacher's explanation, then students take notes so that science learning becomes boring. Science learning is very important for the next generation of the nation so it needs to be presented in the form of active, innovative, imaginative, interesting and fun learning. This learning condition was very visible in grade $V$ when science learning was taking place, some students were less interested. Especially during the hours of the day.

As a result, the implementation of science learning has not been maximally implemented. As a result of science learning which is still centered on the teacher, the quality of science learning in grade $\mathrm{V}$ is still lacking. In order to carry out an effective and efficient learning process, a science learning method is needed, one of which uses the jigsaw cooperative learning model as the most appropriate method in science learning. Basically, science learning activities, in addition to making students master the targeted material, are also directed at developing process skills that are useful to help solve problems. Science directs students in process skills to produce good cognitive results.

One indicator of the low quality of our education is that students are less able to solve the contextual problems they face (Berger \& Henze, 2015; Karacop \& Doymus, 2013). This is because the learning process focuses on memorizing materials and procedures without ever being confronted with reality in the field. This indicates that more effort is needed to improve the quality of student learning outcomes. So far, the learning process that occurs is still applying conventional methods of lectures. This learning method makes students more dependent on the teacher and assumes that if there is no teacher there is no teaching and learning process. In addition, students are not ready to accept lessons and are less active during the teaching and learning process. The learning process is a person's change process that can be assessed as a result of the changes made. In a good learning process, an appropriate learning strategy is needed so that the learning process can be said to be successful (Alavi, Marakas, Yoo, 2002; Doymus, 2008; Mengduo \& Xiaoling, 2010). To achieve the goals of learning science in class $V$ and as an effort to improve the quality of learning, science learning innovations that are currently being developed are the jigsaw cooperative model.

The jigsaw cooperative learning model is a learning model that is able to invite students to think actively and creatively in the learning process. This model not only develops intellectual abilities but all existing potential, including emotional development and skills 
development. Science process skills are basic skills that facilitate learning in science, enable students to be active, develop a sense of responsibility, improve learning and research methods (Gürses et al., 2015; Huang, Liao, Huang, Chen, 2014; Moskowitz, Malvin, Schaeffer, Schaps, 1985). Science process skills are a person's skills in using thoughts, reasoning and actions effectively and efficiently to achieve certain results. Science process skills help students to develop a sense of responsibility in learning and increase the importance of research methods in the learning process (Huang, Huang, Hsieh, 2008; Ongowo \& Indoshi, 2013). Science process skills aim to make students more active in understanding and mastering the series they do. By applying this learning model, it will train students to dare to express opinions, cooperate, develop themselves, and be individually responsible for positive interdependence, personal interactions and group processes. The use of this learning model effectively and efficiently will reduce the monopoly of teachers in mastering the learning process, and students' boredom in receiving lessons will decrease (Hadeen, 2003).

Based on several studies in education, it is reported that the application of cooperative learning models can motivate and involve students in the teaching and learning process to improve learning outcomes (Tsay \& Brady, 2010). Methods are well-thought-out and orderly ways of accomplishing an objective. Method is one of the tools to achieve the goal. while learning is an activity carried out by the teacher in such a way that student behavior changes for the better (Özgelen, 2012). Another understanding says that the learning method is a presentation technique that is mastered by the teacher for teaching or presenting learning material to students in the class either individually or in groups so that the lesson can be absorbed, understood, and utilized by students properly.

Learning is a process of interaction between students and educators and learning resources in a learning environment. Learning is an aid provided by educators so that the process of acquiring knowledge and knowledge can occur. So it can be said that learning theory is an attempt to describe how humans learn, thus helping us understand the complex internal process of learning. The learning method is a method or path taken by the teacher to deliver learning material so that learning objectives can be achieved. It can also be concluded that the learning method is a learning strategy used by the teacher as a medium to achieve predetermined learning objectives. Learning outcomes are patterns of actions, values, understandings, attitudes, appreciation and skills. Learning outcomes are changes in overall behavior, not just one aspect of human potential. meaning that learning outcomes are not seen in a fragmentation or separately but rather comprehensively (Harlen, 1999; Roth \& Roychoudhury, 1993; Souvignier \& Kronenberger, 2007). Thus it can be said that learning outcomes are changes in overall behavior. To achieve maximum results, the five elements in the cooperative learning model must be applied. The five elements are: Positive interdependence (positive interdependence), Personal responsibility (individual responsibility), Face to face primitive interaction, Interpersonal skills (communication between members), and Group processing (group processing). Based on the understanding expressed above, there is an agreement between students and teachers and students and students to collaborate to solve a problem in learning in collaborative ways such as solving problems that occur in students' social life.

Science learning process skills in general and natural science education at SD Negeri Tunjungsari 2, there is a need for development and understanding in the field of education, among others, related to the learning model applied in the teaching and learning process. This is related to science education so far has not succeeded in improving the quality of students' understanding of science concepts and rules because we are wrong or do not choose the learning model. Learning science in the classroom is inseparable from student teaching and learning activities. Science learning must be carried out using appropriate methods and in accordance with the level of development of elementary school children. If the assignments can be done properly, students will be able to achieve the minimum completeness criteria standard (KKM) set by the school.

As an educational institution, schools play an important role in preparing the nextgeneration. The teacher's role is very large in all learning activities. The teacher's task is 
not only to convey learning material, but the teacher should be able to instill the correct concepts from the learning material so that the knowledge that students learn can benefit students' lives, now and in the future. Teaching and learning activities in science lessons at SD Negeri Tunjungsari 2 still experience many problems. Often encountered passive students, do not have the courage to express their opinions or ideas, do not dare to ask the teacher when they experience difficulties in learning. In addition, students still do not understand the material entered by the teacher even though the material is given repeatedly. The ability of students to learn science learning outcomes is still very low (average 65). In addition, students who succeed in achieving KKM are less than $75 \%$ of the KKM content in science lessons.

Various fundamental problems faced by our national education today are reflected in the reality of the education we live in. In the context of learning models and methods in schools, for example, most teachers are still less creative. In fact, you could say they are less innovative, considering that the learning methods used are still very monotonous, this clearly will not create graduates who can think critically, creatively, and independently. This type of jigsaw cooperative method will improve the maximum learning process skills. This study was aimed at is to find out how the jigsaw cooperative learning model can improve learning outcomes in human breathing material in science subject content for fifth grade students of SD Negeri Tunjungsari 2, Kalasan, Sleman. In addition, the purpose of this classroom action research is also to find out whether the jigsaw cooperative learning model can improve process skills and learning outcomes in human respiration material in science subject content for fifth grade students of SD Negeri Tunjungsari 2, Kalasan, Sleman.

\section{Method}

The type of Classroom Action Research used in this research is collaborative, namely that people who will take action must also be involved in the research process from the start. Classroom action research is an examination of learning activities in the form of an action that is deliberately raised and occurs in the classroom together in activities carried out by students (Arikunto, 2010). This research is a Classroom Action Research model of Kemmis and MC Taggart. This research was carried out in 2 cycles using the type of jigsaw cooperative learning model on the fifth grade science learning outcomes of SD Negeri Tunjungsari 2 because the teachers only used the method. lectures continuously, there is no variation in student interest in low science subject matter, students are passive in learning, do not pay attention to the teacher when explaining and the results are very lacking. This research is a qualitative descriptive study. This research is also a qualitative descriptive research, which is a type of research that only describes, summarizes various conditions, situations, or various variables. In this research, the concrete conditions of the research object will be described, connecting one variable or condition with other variables or conditions and then a description of the research object will be generated. The research was conducted in the first semester of the 2019/2020 school year from August to October 2019 at SD Negeri Tunjungsari 2 . There were 30 students in grade V, namely 16 male students and 14 female students. This research was conducted in 2 cycles, the first cycle was carried out with 3 lessons and the second cycle was carried out with 3 lessons. Each cycle goes through steps: Planning, Action, Observation, Reflection.

\section{Results and Discussion Results}

The results showed that the use of the type of jigsaw cooperative learning model can improve the learning outcomes of fifth grade students of human breathing material, the average value of learning outcomes in cycle II is 86.66 with very good classification. The initial condition of science learning during the initial research when the teacher entered the study room with a frowning or gloomy face, the learning process could be expected to take place in a tense, tiring, and boring atmosphere. During the learning process the student's soul is in discomfort, there is a problem with low learning outcomes, the completeness of learning outcomes can be reported as a class average score of 57.33 students have 
completed learning 33\% and students have not completed learning $67 \%$. These conditions need a learning innovation effort to solve problems in class $\mathrm{V}$, one of which is using a learning method that attracts the jigsaw cooperative model. Cycle I using the jigsaw cooperative learning model, students are more interested and student learning outcomes have increased with the class average score being 82.66 students have completed learning $87 \%$ and students have not finished learning $13 \%$. With these improvements, the results of learning science subject matter human breathing in cycle II have been able to run well the class average value is 86.66 students have finished learning $100 \%$ and students have not finished learning $0 \%$. Improvement of process skills and learning outcomes is seen in cycles I and II.

Based on the comparison of student learning outcomes in the initial research, in the first cycle and in the second cycle, seen from the comparison of the average value, in the initial study the class average value was 57.33 , in the first cycle the class average was 82.66 and at cycle II the class average becomes 86.66. In addition, the number of students who passed has also increased, in the initial study only 10 students (33\%) passed, and 20 others $(67 \%)$ did not pass. In the first cycle, the number of students who passed increased to 26 $(87 \%)$ students who did not pass were $4(13 \%)$. The increase in the number of students who passed was also seen in cycle II, the number of students who passed was 30 people $(100 \%)$ or in other words all students passed.

Table 1. Comparison of Study Result Test Data

\begin{tabular}{llccccr}
\hline No & Recap of Test Results & $\begin{array}{c}\text { Initial } \\
\text { Test } \%\end{array}$ & Cycle I $\%$ & \multicolumn{2}{c}{$\begin{array}{c}\text { Cycle II } \\
\%\end{array}$} \\
\hline 1 & The number of students who passed & $\begin{array}{c}10 \\
33 \%\end{array}$ & 26 & $87 \%$ & 30 & 100 \\
\hline $2 \quad \begin{array}{l}\text { The number of students who did not } \\
\text { pass }\end{array}$ & $\begin{array}{c}20 \\
67 \%\end{array}$ & 04 & $13 \%$ & 0 & $0 \%$ \\
\hline Average & $\mathbf{5 7 . 3 3}$ & $\mathbf{8 2 . 6 6}$ & & $\mathbf{8 6 . 6 6}$ \\
\hline
\end{tabular}

\section{Discussion}

The use of the jigsaw cooperative method can improve student learning outcomes in human breathing material. Each group must work together and communicate in solving existing problems. In the discussion, it is possible to exchange opinions and ideas from each student. Discussions that occur between students will add new insights to students in human breathing material so that students become clear

This discussion refers to the data obtained during the implementation of the action by applying the jigsaw cooperative model in science learning about human breathing at SD Negeri Tunjungsari 2, Kalasan District, Sleman Regency, as an effort to improve student learning outcomes. The findings obtained based on the formulation of the problem are: First, based on planning, preparation I and preparation II in cycle I are planned as the first step to build a solid foundation in class by making a joint commitment. Students have a voice in determining the rules and consequences of learning, so that learning is more controlled and students are more responsible for what they do. Second, based on implementation, the teacher is able to focus himself and students on learning, appreciate the efforts of students in doing assignments or questions, and are friendly in behaving and communicating.

The attitude of respect shown by the teacher to students has a positive effect on student comfort and student activity in learning. This was evidenced by the fact that students began to relax when sitting with a series of sincere smiles showing the blush of the students' faces. When compared to science learning at the time of initial research, the implementation of the first cycle of action has increased even though it has not reached the expected target. Activities carried out in science learning are carried out as an effort to provide learning experiences to students.

The jigsaw cooperative learning model is a learning model that is able to invite students to think actively and creatively in the learning process. This model not only develops 
intellectual abilities but all existing potential, including emotional development and skills development. Science process skills are basic skills that facilitate learning in science, enable students to be active, develop a sense of responsibility, improve learning and research methods (Gürses et al., 2015; Huang, Liao, Huang, Chen, 2014; Moskowitz, Malvin, Schaeffer, Schaps, 1985). Science process skills are a person's skills in using thoughts, reasoning and actions effectively and efficiently to achieve certain results. Science process skills help students to develop a sense of responsibility in learning and increase the importance of research methods in the learning process (Huang, Huang, Hsieh, 2008; Ongowo \& Indoshi, 2013). Science process skills aim to make students more active in understanding and mastering the series they do. By applying this learning model, it will train students to dare to express opinions, cooperate, develop themselves, and be individually responsible for positive interdependence, personal interactions and group processes. The use of this learning model effectively and efficiently will reduce the monopoly of teachers in mastering the learning process, and students' boredom in receiving lessons will decrease (Hadeen, 2003).

Based on several studies in education, it is reported that the application of cooperative learning models can motivate and involve students in the teaching and learning process to improve learning outcomes (Tsay \& Brady, 2010). Methods are well-thought-out and orderly ways of accomplishing an objective. Method is one of the tools to achieve the goal. while learning is an activity carried out by the teacher in such a way that student behavior changes for the better (Özgelen, 2012). Another understanding says that the learning method is a presentation technique that is mastered by the teacher for teaching or presenting learning material to students in the class either individually or in groups so that the lesson can be absorbed, understood, and utilized by students properly.

Learning is a process of interaction between students and educators and learning resources in a learning environment. Learning is an aid provided by educators so that the process of acquiring knowledge and knowledge can occur. So it can be said that learning theory is an attempt to describe how humans learn, thus helping us understand the complex internal process of learning. The learning method is a method or path taken by the teacher to deliver learning material so that learning objectives can be achieved. It can also be concluded that the learning method is a learning strategy used by the teacher as a medium to achieve predetermined learning objectives. Learning outcomes are patterns of actions, values, understandings, attitudes, appreciation and skills. Learning outcomes are changes in overall behavior, not just one aspect of human potential. meaning that learning outcomes are not seen in a fragmentation or separately but rather comprehensively (Harlen, 1999; Roth \& Roychoudhury, 1993; Souvignier \& Kronenberger, 2007). Thus it can be said that learning outcomes are changes in overall behavior. To achieve maximum results, the five elements in the cooperative learning model must be applied. The five elements are: Positive interdependence (positive interdependence), Personal responsibility (individual responsibility), Face to face primitive interaction, Interpersonal skills (communication between members), and Group processing (group processing). Based on the understanding expressed above, there is an agreement between students and teachers and students and students to collaborate to solve a problem in learning in collaborative ways such as solving problems that occur in students' social life.

\section{Conclusions and Suggestions}

Based on the discussion and results of research carried out in science learning through the application of the jigsaw cooperative model that the implementation of the jigsaw cooperative model learning method in class V SD Negeri Tunjungsari 2, Kalasan, Sleman science subject matter Human Respiratory Material can improve student learning outcomes. There was an increase in student learning outcomes in science learning, namely in the initial research, in cycle I and in cycle II. In addition, the number of students who passed has also increased, The increase in science learning outcomes is indicated by an increase in the class average score. 


\section{References}

Alavi, M., Marakas, G. M., \& Yoo, Y. (2002). A comparative study of distributed learning environments on learning outcomes. Information Systems Research, 13(4), 404-415. https://doi.org/10.1287/isre.13.4.404.72.

Arends, R. (1997). Classroom injstruction and managemen. New York : Mc Graw Hill Companies.

Arikunto, S. (2010). Dasar-Dasar Evaluasi Pendidikan. Rineka Cipta

Beaumont-Walters, Y., \& Soyibo, K. (2001). An analysis of high school students' performance on five integrated science process skills. Research in Science \& Technological Education, 19(2), https://doi.org/10.1080/02635140120087687.

133-145.

Berger, R., \& Hänze, M. (2015). Impact of expert teaching quality on novice academic performance in the jigsaw cooperative learning method. International Journal of Science Education, 37(2), 294-320. https://doi.org/10.1080/09500693.2014.985757.

Brotherton, P. N., \& Preece, P. F. (1995). Science process skills: Their nature and interrelationships. Research in Science \& Technological Education, 13(1), 5-11. https://doi.org/10.1080/02635140120087687.

Cahyani, N. W. T., Ardana, I. K., \& Ganing, N. N. (2016). Penerapan Pendekatan Saintifik Berbantuan Project Based Learning Untuk Meningkatkan Hasil Belajar IPA Siswa Kelas V. Mimbar PGSD Undiksha, 4(1). http://dx.doi.org/10.23887/jjpgsd.v4i1.7124.

Cooper, J. (1990). Cooperative learning and college instruction: Effective use of student learning teams. Calivornia State University Institute for Teaching and Learning

Doymus, K. (2008). Teaching chemical bonding through jigsaw cooperative learning. Research in Science \& Technological Education, 26(1), 47-57. https://doi.org/10.1080/02635140701847470.

Gürses, A., Çetinkaya, S., Doğar, Ç., \& Şahin, E. (2015). Determination of levels of use of basic process skills of high school students. Procedia-Social and Behavioral Sciences, 191, 644-650. https://doi.org/10.1016/J.SBSPRO.2015.04.243.

Harden, R. M. (2002). Learning outcomes and instructional objectives: is there a difference?. Medical teacher, 24(2),

https://doi.org/10.1080/0142159022020687.

151-155.

Harlen, W. (1999). Purposes and procedures for assessing science process skills. Assessment in Education: principles, policy \& practice, 6(1), 129-144. https://doi.org/10.1080/09695949993044.

Hedeen, T. (2003). The reverse jigsaw: A process of cooperative learning and discussion. Teaching sociology, 31(3), https://www.jstor.org/stable/3211330?seq=1.

Huang, Y. M., Huang, T. C., \& Hsieh, M. Y. (2008). Using annotation services in a ubiquitous Jigsaw cooperative learning environment. Journal of Educational Technology \& Society, 11(2), 3-15. https://www.jstor.org/stable/jeductechsoci.11.2.3.

Huang, Y. M., Liao, Y. W., Huang, S. H., \& Chen, H. C. (2014). Jigsaw-based cooperative learning approach to improve learning outcomes for mobile situated learning. Journal of Educational Technology \& Society, 17(1), 128-140. https://www.jstor.org/stable/pdf/jeductechsoci.17.1.128.pdf.

Hussey, T., \& Smith, P. (2008). Learning outcomes: a conceptual analysis. Teaching in higher education, 13(1), 107-115. https://doi.org/10.1080/13562510701794159. 
Karacop, A., \& Doymus, K. (2013). Effects of jigsaw cooperative learning and animation techniques on students' understanding of chemical bonding and their conceptions of the particulate nature of matter. Journal of Science Education and Technology, 22(2), 186-203. https://doi.org/10.1007/s10956-012-9385-9.

Krisno, B. A. (2016). SINTAKS 45 Model Pembelajaran Dalam Student Centered Learning (SCL). Universitas Muhammadiyah Malang.

Lai, C. Y., \& Wu, C. C. (2006). Using handhelds in a Jigsaw cooperative learning environment. Journal of Computer Assisted Learning, 22(4), 284-297. https://doi.org/10.1111/j.1365-2729.2006.00176.x.

Mengduo, Q., \& Xiaoling, J. (2010). Jigsaw Strategy as a Cooperative Learning Technique: Focusing on the Language Learners. Chinese Journal of Applied Linguistics (Foreign Language Teaching \& Research Press), 33(4).

Moskowitz, J. M., Malvin, J. H., Schaeffer, G. A., \& Schaps, E. (1985). Evaluation of jigsaw, a cooperative learning technique. Contemporary educational psychology, 10(2), 104112. https://doi.org/10.1016/0361-476X(85)90011-6.

Novianto, A. \& Mustadi, A. (2015). The analysis of integrative thematic content, scientific approach, and authentic assessment in elementary school textbooks. Yogyakarta: Universitas Negeri Yogyakarta. JurnalKependidik $\neg a n, 45$ (1) Mei 2015. Dari http://journal.uny.ac.id/index.php/jk/article/view/7181/6192.

Ongowo, R. O., \& Indoshi, F. C. (2013). Science process skills in the Kenya certificate of secondary education biology practical examinations. Creative Education, 04(11), 713-717. https://doi.org/10.4236/ce.2013.411101.

Özgelen, S. (2012). Students' science process skills within a cognitive domain framework. Eurasia Journal of Mathematics, Science and Technology Education, 8(4), 283-292. https://doi.org/10.12973/eurasia.2012.846a.

Roth, W. M., \& Roychoudhury, A. (1993). The development of science process skills in authentic contexts. Journal of Research in Science Teaching, 30(2), 127-152. https://doi.org/10.1002/tea.3660300203.

Souvignier, E., \& Kronenberger, J. (2007). Cooperative learning in third graders' jigsaw groups for mathematics and science with and without questioning training. British Journal of Educational Psychology, 77(4), 755-771. https://doi.org/10.1348/000709906X173297.

Trigwell, K., \& Prosser, M. (1991). Improving the quality of student learning: the influence of learning context and student approaches to learning on learning outcomes. Higher education, 22(3), 251-266. https://doi.org/10.1007/BF00132290.

Tsay, M., \& Brady, M. (2010). A Case Study of Cooperative Learning and Communication Pedagogy: Does Working in Teams Make a Difference? Journal of the Scholarship of Teaching and Learning, 10(2), 78-89. https://eric.ed.gov/?id=EJ890724. 